\title{
Encrinus aculeatus von Meyer, 1849 (Crinoidea, Encrinidae) from the Middle Triassic of Val Brembana (Alpi Orobie, Bergamo, Italy)
}

\author{
Hans Hagdorn ${ }^{1}$ (1) $\cdot$ Fabrizio Berra ${ }^{2} \cdot$ Andrea Tintori $^{3}$
}

Received: 27 June 2018/Accepted: 12 October 2018/Published online: 1 November 2018

(c) Akademie der Naturwissenschaften Schweiz (SCNAT) 2018

\begin{abstract}
The Triassic crinoid Encrinus aculeatus is described from a single bedding plane of uncertain Pelsonian or early Illyrian or (less probable) late Ladinian origin from Val Brembana (Alpi Orobie, Bergamo, Italy) based on 36 more or less complete crowns and columns. The specimens represent an obrutional echinoderm lagerstätte of the Muschelkalk type. The individuals are semi-adult and juvenile; adult individuals are lacking. Morphological description and comparison with the holotype and additional material from the Lower Muschelkalk and basal Middle Muschelkalk of Upper Silesia (Poland) prove the assignment to Encrinus aculeatus. However, the species concept of genus Encrinus is critical because several characters are inconsistent. E. aculeatus occurs in the Middle Triassic (Bithynian to early Illyrian, ? early Ladinian) of the western Tethys shelf and Peritethys basins (Southern Alps, Balaton Upland, Germanic Basin). Encrinus aculeatus is regarded ancestral to the Upper Muschelkalk (latest Illyrian) E. liliiformis. Until now, E. liliiformis has not yet been proven with certainty from outside the Germanic Basin; references are based on isolated and undiagnostic material.
\end{abstract}

Keywords Benthic crinoids $\cdot$ Encrinida $\cdot$ Middle Triassic $\cdot$ Tethys $\cdot$ Muschelkalk $\cdot$ Italy $\cdot$ Alpi Orobie

\begin{tabular}{|c|c|}
\hline \multicolumn{2}{|c|}{ Abbreviations } \\
\hline BGR & $\begin{array}{l}\text { Bundesanstalt für Geowissenschaften und } \\
\text { Rohstoffe, Berlin }\end{array}$ \\
\hline GIUS & $\begin{array}{l}\text { Geological Institute Silesian University } \\
\text { Sosnowiec }\end{array}$ \\
\hline MHI & Muschelkalkmuseum Hagdorn Ingelfingen \\
\hline MPUM & $\begin{array}{l}\text { Paleontological Museum-Dipartimento di } \\
\text { Scienze della Terra 'A.Desio', UNIMI }\end{array}$ \\
\hline NLH & Niedersächsisches Landesmuseum Hannover \\
\hline SBG & Collection Bielert Göttingen \\
\hline
\end{tabular}

Editorial Handling: C. Klug.

Hans Hagdorn

encrinus@hagdorn-ingelfingen.de

1 Muschelkalkmuseum Ingelfingen, Schloss-Straße 11, 74653 Ingelfingen, Germany

2 Dipartimento di Scienze, della Terra 'A. Desio', Via Mangiagalli 34, 20133 Milano, Italy

3 Triassica-Institute for Triassic Lagerstaetten, Perledo, LC, Italy

\section{Introduction}

During Middle Triassic times, the crinoid family Encrinidae inhabited shallow marine areas of the entire Western Tethys and Peritethys realm. However, only a few complete encrinid cups and crowns determinable at genus or species level have hitherto been described from outside the Germanic Basin (Benecke 1868; Hildebrand and Pia 1929). Unlike the Germanic Muschelkalk with its well-studied echinoderm conservation lagerstätten that yielded a plethora of perfectly preserved articulated and complete specimens, Middle Triassic crinoid remains from the Alps are mostly confined to crinoidal limestones (encrinites) with accumulations of disarticulated material of low diagnostic significance. Hence, all Middle Triassic encrinid species and genera were established based on Muschelkalk specimens. Moreover, encrinid-like columnals mentioned in the stratigraphical and palaeoecological literature dealing with the Alpine Middle Triassic were generally assigned to the small-sized Dadocrinus gracilis or to Encrinus liliiformis. However, the latter species has not been proven with certainty from the Alpine Triassic.

An encrinid cup and isolated cup elements from the Anisian Recoaro Formation (Calcare a Brachiopodi) of Recoaro (Vicentinian Prealps, Italy) figured by Benecke 
(1868: pl. 4) were assigned to Encrinus sp. and Encrinus carnalli (now Carnallicrinus, Family Dadocrinidae); the latter cup (Benecke 1868: pl. 4, Fig. 1a-c) could also belong to Encrinus robustus Assmann 1926. Hildebrand and Pia (1929) emphasized the importance of two findings of articulated encrinid crowns from the Southern Alps: (1) a fragmentary specimen from the Anisian Braies (Prags) Formation of the Dolomites (South Tyrol, Italy) showing four arms from the first primibrachial almost to the tips was assigned with reservation to Encrinus robustus by Hildebrand (in Hildebrand and Pia 1929), (2) an almost complete but strongly weathered crown was collected by von Arthaber (1896) in the debris of an abandoned quarry below Cappella Rotonda in Giudicarie (Lombardy, Italy) derived from the topmost part of the Angolo Formation or basal Prezzo Limestone (Cimego Limestone Autorum, but see Gaetani 1969) (Anisian). This specimen was assigned by Hildebrand (in Hildebrand and Pia 1929) and Gasche (1938) to Encrinus aculeatus von Meyer, 1849. Types and additional material of both species figured and described by Assmann (1926, 1937) come from the Anisian Lower Muschelkalk (Upper Gogolin, Górażdze, and Karchowice formations) of Upper Silesia (SW Poland, formerly Oberschlesien, Germany). Encrinus aculeatus and robustus also occur in the Lower Muschelkalk (Jena Formation) of Germany (Wagner 1886, 1891, Emmert et al. 1972, Bielert and Bielert 2000). For a full list of references see Biese (1934). To date, no further diagnostic encrinid material has emerged from outside the Germanic Basin.

Hence, the encrinid material described below contributes to the knowledge of the Alpine Middle Triassic crinoid fauna. The specimens are compared to historical and new material from the type area in Poland and from Germany.

\section{Locality and stratigraphy}

Two slabs with remains of altogether 36 crinoids were collected by unknown private collectors in Val Brembana (Alpi Orobie, Bergamo, Lombardy, Italy) at an elevation of approx. $2000 \mathrm{~m}$ from loose blocks. Formation and age are unidentified. In the study area, a succession spanning from the Anisian to late Ladinian crops out (Jadoul et al. 2012; Fig. 1). The succession records two successive carbonate platform systems. The lower one (early through middle Anisian in age) is characterized by peritidal dolostones of the Camorelli Limestone covering subtidal, burrowed bioclastic packstones and wackestones of the Angolo Limestone (Berra et al. 2005). The upper system is characterized by a high-relief, steep-sloped carbonate platform (Esino Limestone) prograding over basinal sediments consisting of ammonoid-bearing marly limestones
(Prezzo Limestone of Illyrian age), postdating the drowning of the underlying peritidal facies of the Camorelli Limestone after local subaerial exposure (Assereto and Casati 1965; Balini 1992). Dark fine-grained limestones are present in the upper part of the Esino Limestone, interpreted as deposits of intraplatform troughs (Wengen Formation and Perledo Varenna Limestone). The transition from the lower to the upper system is marked by a sharp surface (the top of the Camorelli Limestone) paraconformably covered by 5-10 $\mathrm{m}$ of bioclastic packstones within the Prezzo Limestone referred to as "Banco a Brachiopodi" (a brachiopod lumachelle, Gaetani et al. 1986). This unit consists of burrowed, poorly-bedded bioclastic packstones, floatstones, and wackestones characterized by the presence of abundant crinoid ossicles and locally brachiopods (Jadoul et al. 2012). This unit is characterized by the occurrence of the foraminifers Pilammina densa and Palaeomiliolina judicariensis (Gaetani et al. 1986). The age of the "Banco a Brachiopodi" is ascribed to the base of the Illyrian (cimeganus Zone, Monnet et al. 2008). The "Banco a Brachiopodi" can be traced all across the Lombardy Basin and represents an important marker bed that separates the two different carbonate systems of Anisian and Ladinian age, respectively. This unit is considered to register the drowning of the Anisian platform and reduced sedimentation (Berra et al. 2005, Jadoul et al. 2012) documented by abundant brachiopods and by intensive bioturbation in deposits rich in skeletal grains (mostly crinoid ossicles but also pelagic bivalves at the base; Jadoul et al. 2012).

Because the crinoid slabs have been collected from loose blocks in a poorly defined area, the attribution of the samples to a definite lithostratigraphic unit can rely only upon lithological comparison between the sample and the general characteristics of the units cropping out in this area. The studied sample consists of dark, fine-grained, bedded wackestone containing crinoid ossicles and rare thin-shelled bivalves. According to the facies association, the sample can be derived from four of the units described: (1) the Angolo Limestone, (2) "Banco a Brachiopodi", (3) the Prezzo Limestone, (4) the Perledo Varenna Limestone. The Esino Limestone (massive light-coloured carbonates) and the Camorelli Limestone (grey peritidal stromatolitic dolostone with a typical fenestrate fabric) can be excluded because of major lithological differences. Considering the four units and the presence of crinoids in the sample, the Angolo Limestone or the "Banco a Brachiopodi" is the most probable source. Actually, the Prezzo Limestone can be excluded because of the presence of marls, the dominance of mudstone and the typical occurrence of white mica that is completely absent in the studied sample; furthermore, crinoids are rare in the Prezzo Limestone. The Perledo Varenna Limestone consists of well-bedded 


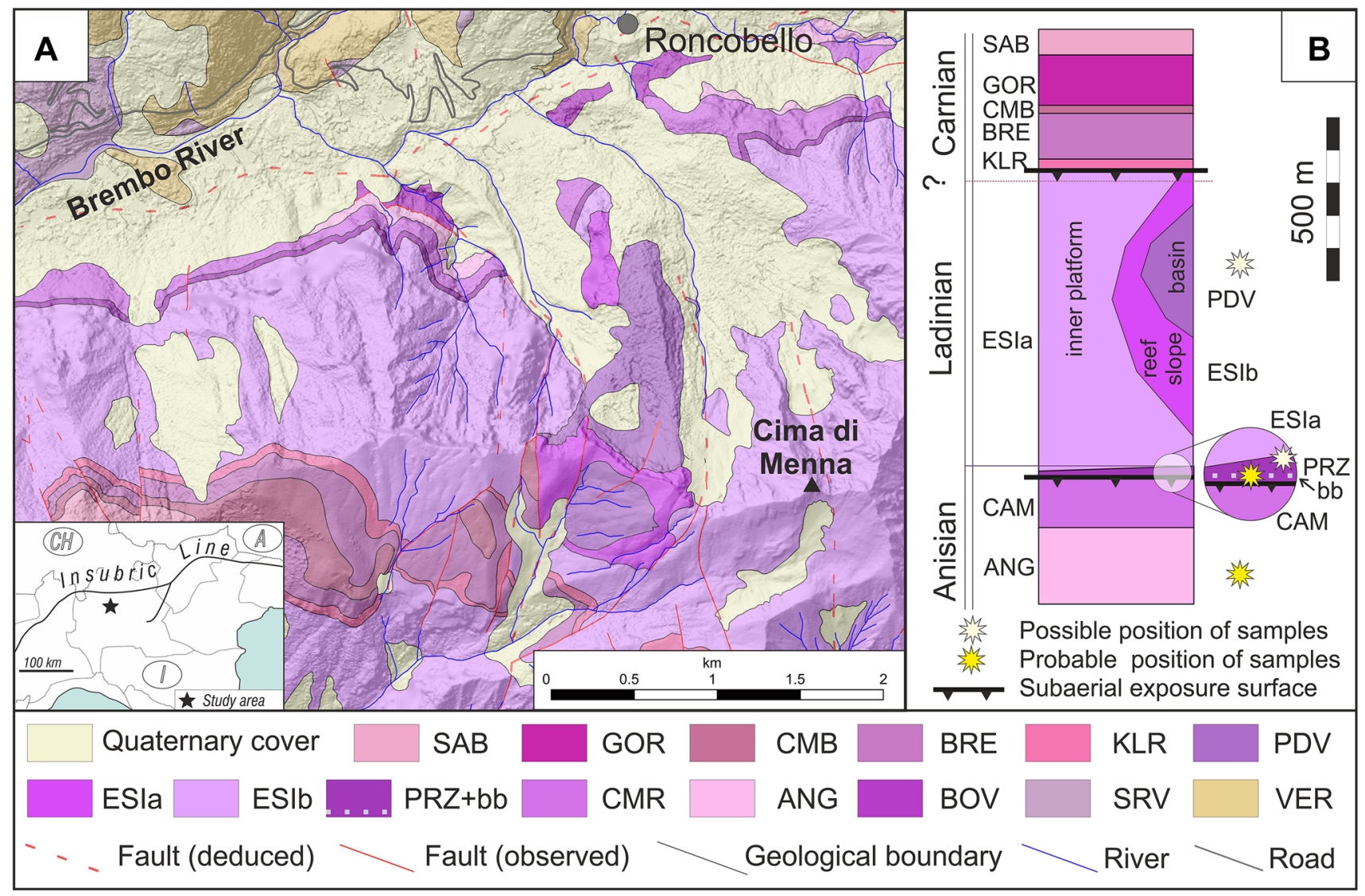

Fig. 1 Simplified geological map (from Jadoul et al. 2012) of the area of provenance of the samples (a) and schematic stratigraphic section of the Anisian-Carnian succession (b). VER Verrucano Lombardo, $S R V$ Servino, BOV Carniola di Bovegno, $A N G$ Angolo Limestone, $C A M$ Camorelli Limestone, PRZ Prezzo Limestone ( $b b$ Banco a

limestone, and thus should be a possible source for the samples; however, crinoids are not so abundant. Crinoids are abundant in the Angolo Limestone and especially in the "Banco a Brachiopodi". The Angolo Limestone is in general characterized by bioturbated mudstones with dispersed crinoids and foraminifera and by dark, thin-bedded to massive bioturbated limestones with thin marly layers. Upsection, the Angolo Limestone grades into peritidal dolostone of the Camorelli Formation. In the "Banco a Brachiopodi", instead, crinoids are abundant, even if they are usually disarticulated. In general, the "Banco a Brachiopodi" is characterized by intensive bioturbation that typically produces a pseudonodular aspect. Although bedding is poor, it is possible to observe locally bedded intervals. Such bedded, transgressive facies with crinoids and pelagic bivalves are reported at the base of the "Banco a Brachiopodi" in the study area (Jadoul et al. 2012).

According to these considerations, the best candidate for the provenance of the studied slabs is the early Illyrian "Banco a Brachiopodi". However, the bedded facies of the Pelsonian Angolo Limestone cannot be excluded.
Brachiopodi at the base), BUC Buchenstein Formation, PDV PerledoVarenna Limestone, ESIa Esino Limestone, inner platform facies, ESIb Esino Limestone, reef and slope facies, LOZ Lozio Shale, BRE Breno Formation, $C M B$ Calcare Metallifero Bergamasco, GOR Gorno Formation, $S A B$ Val Sabbia Sandstone

\section{Description}

\section{Overview}

The material comprises two slabs with altogether 36 more or less complete crowns, arms and column fragments. Slab 1 (MPUM 11758) measuring $26 \times 16 \mathrm{~cm}$ contains 27 specimens, some of them with remains of proximal columns (Fig. 2a). Slab 2 (collection M. Salmoiraghi, uncatalogued) measuring $20 \times 17 \mathrm{~cm}$ contains nine crowns and crown fragments (Fig. 2b); the original specimen was available for study; resin casts are kept in MPUM and MHI. Both slabs are derived from the same bed of a 5-cmthick black micritic limestone which became dark grey after weathering. It was covered by a 2 -mm-thick sheet of similar micritic limestone, which is still preserved along one margin of the slabs. The two layers are separated by an extremely thin joint. Due to pressure solution, the surface of the lower bedding plane is coarse and uneven. Pressure solution affected also the surface of the cover bed, however, at a minor extent. The crinoid crowns are in lateral 
Fig. 2 Encrinus aculeatus, crowns, arms, column fragments, Val Brembana (Alpi Orobie, Italy). ? Angolo Limestone (Pelsonian), ? "Banco a Brachiopodi", (early Illyrian). a MPIUM11758 (Slab 1). b Private collection M. Salmoiraghi (Slab 2)

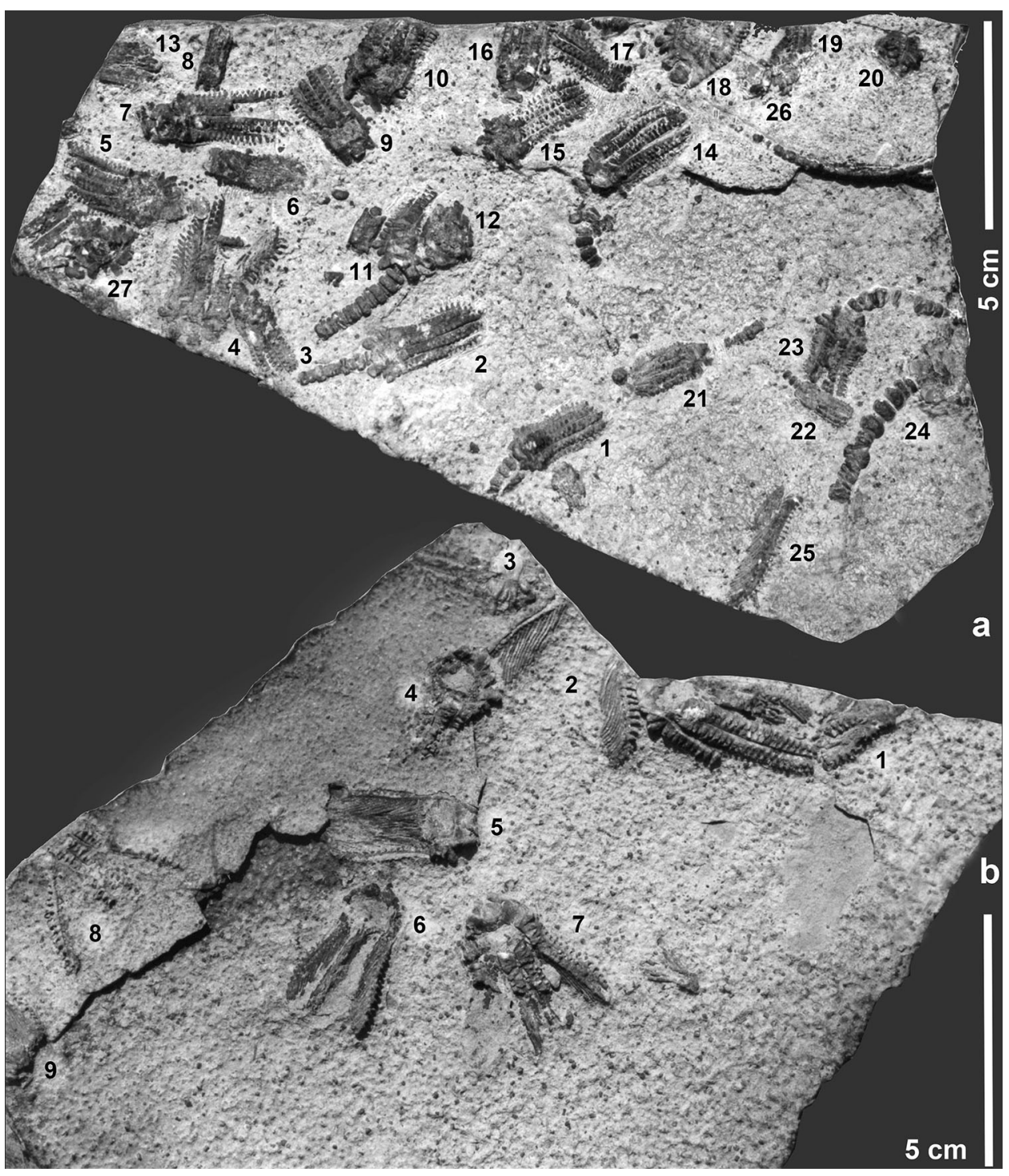

position, most of them with their arms closed, and half embedded into the underlying lower limestone. Their upper sides are partly covered by the micritic sheet as far as it is still preserved. The most elevated parts of some of the crowns at the proximal arms remained in the cover sheet and were lost when the two layers were separated. However, by this splitting the pinnulation of some arms became visible. The crinoids are preserved in a dark blocky calcite. There was no attempt to additionally prepare them from the hard matrix. Assumably, the thin limestone sheet resulted from a smothering event lethal for the crinoids, which, however, preserved them as articulated skeletons. This is evidenced by two dominating directions of the long axes of the crinoid crowns following bottom currents. Some of the crowns are preserved with more or less long parts of their proximal columns attached. Presumably, more distal parts of the columns and possibly also the holdfasts were lost in the cover sheet. Hence, the crinoids were embedded as complete articulated individuals, probably after being smothered by suspended mud which was subsequently deposited as cover sheet. Therefore, the two slabs represent a typical echinoderm obrutional conservation lagerstätte comparable to the well-known Muschelkalk echinoderm lagerstätten (Seilacher and Westphal 1971). The lack of adult specimens gives additional evidence for a sudden smothering event affecting a population of semi-adult and juvenile individuals. The lower sides of the limestone slabs were etched by hydrochloric acid and turned black and glossy. By this treatment, some weakly silicified crinoid sclerites appeared at the etched surface. However, the limestone is a mudstone with very sparsely distributed delicate crinoid remains.

Figure 2 shows slabs 1 and 2 in overview and the numbering of the individual specimens. Only complete 
Table 1 Measurements of specimens from Val Brembana

\begin{tabular}{|c|c|c|c|c|c|c|c|c|c|c|c|c|c|}
\hline Slab/specimen & $1 / 1$ & $1 / 2$ & $1 / 3$ & $1 / 8$ & $1 / 9$ & $1 / 14$ & $1 / 15$ & $1 / 17$ & $1 / 21$ & $1 / 22$ & $1 / 23$ & $2 / 1$ & $2 / 7$ \\
\hline Overall length of crown & 24.9 & 31.0 & 23.4 & 15.9 & 26.4 & 31.3 & 32.0 & - & 22.8 & 16.0 & - & $\sim 41$ & $\sim 32$ \\
\hline Diameter of cup & 8.0 & 10.3 & 7.5 & 5.7 & 9.4 & $\sim 11.3$ & 10.6 & - & 8 & $\sim 5.5$ & 10.5 & - & $\sim 11$ \\
\hline Crown diameter at axillaries & 12.4 & 14.5 & $\sim 9$ & $\sim 7$ & - & $\sim 17.5$ & 16.0 & - & 8 & - & 15.2 & - & - \\
\hline Arm length from mid of axillaries & 21.4 & 24.7 & - & - & 19.9 & $\sim 24.5$ & $\sim 24$ & $\sim 24$ & 11.8 & - & - & $\sim 30$ & $\sim 24.5$ \\
\hline Arm width at mid arm length & 1.8 & 2.0 & 2.0 & $\sim 1.5$ & - & 3.5 & 3.5 & 3.0 & 2.2 & 1.7 & $\sim 3.5$ & 4.0 & $\sim 3.5$ \\
\hline Maximum arm width & 2.5 & 2.5 & 2.4 & $\sim 1.5$ & 3.4 & 4.7 & 4.0 & 3.7 & - & 1.7 & 4.2 & 4.0 & - \\
\hline Secundibrachial number in a row & 17 & $\begin{array}{l}20 \\
(+)\end{array}$ & 14 & - & $\sim 16$ & $19(+)$ & $\sim 19$ & $\begin{array}{l}17 \\
(+)\end{array}$ & - & - & - & 23 & $15(+)$ \\
\hline $\begin{array}{l}\text { Begin of biseriality at } \\
\text { secundibrachial number }\end{array}$ & 6 & 6 & 7 & - & 6 & - & - & 7 & 7 & - & 6 & 6 & $\sim 6$ \\
\hline
\end{tabular}

crowns were measured (Table 1 ). These are specimens $1-3,8,9,14,15,17$, and 21-23 from slab 1 , and specimens 1 and 2 from slab 2. Pluricolumnals $1 / 1$ and $1 / 24$ from slab 1 are analyzed in Table 2.

\section{Description of specimens}

General shape The laterally embedded crowns are slightly constricted at the proximal part of the arms (Fig. 3). Juvenile crowns are almost cylindrical (specimens 1/8, 1/21; Fig. 4c). Generally, their articulated preservation does not allow observation of articular facets. In the proximal column, nodals and internodals are distinctly structured; some proximal nodals show cirrus scars. Distally, the columnals become indistinct barrel-shaped.

Table 2 Analysis of two proximal columns of $\mathrm{Val}$ Brembana specimens

\begin{tabular}{ll}
\hline Column $1 / 1$ & Column $1 / 24$ \\
\hline Base & Base \\
N1 & $?$ \\
1IN & N ? clrr (?) \\
N2 cirr & 2IN (?) \\
2 IN & 1IN \\
IIN & N (?) cirr \\
2 IN & 1 IN (?) \\
N3 & 2 IN (?) \\
2 IN & N \\
IIN & 2 IN \\
2 IN & 1 IN \\
N4 cirr & N \\
1 IN & $?$ \\
\hline
\end{tabular}

Cup Due to the preservation of all crowns in lateral position, no cup can be observed in dorsal view. The radials are dorsally extremely inflated; due to these sack-like dorsal extensions, the subhorizontal to horizontal basal circle remains invisible in side view. In specimen $1 / 2$, the cup is dorsoventrally broken and shows the depressed position of the horizontal basal circle and the extent of the dorsal inflations of the radials (Fig. 4b).

Basals None of the specimens shows sutures or even clear outlines of the basals.

Radials In dorsal view, the radials are trapezoid with the sack-like extensions directed downwards. Interradial suture lines are deepened; interradial articulations are zygosynostosial with a moderate depression and faint dorsal crenulation (specimen 1/9; Fig. 4b). The distal radial facets are directed upward, but not visible in any specimen. The suture line with the first primibrachial is medially slightly recessed.

First primibrachial In dorsal view, the first primibrachials are low rectangular with a medially extended proximal suture line (articulation with radial) and a recessed distal suture line. Articulation facets are not visible in any specimen. The sack-like dorsal extensions are directed outwards. A deep gap between the extensions of the radials and the first primibrachials allow outward tilting of the arms at the muscular radial facets (Fig. 5).

Second primibrachial At the axillary second primibrachials the arms are branching (Fig. 3). In dorsal view, axillaries are broad pentagonal with a medially extended proximal suture line, very short lateral and the two distal sutures meeting at an angle of $130^{\circ}-140^{\circ}$. The articular facets are concealed. The dorsal side is strongly inflated 

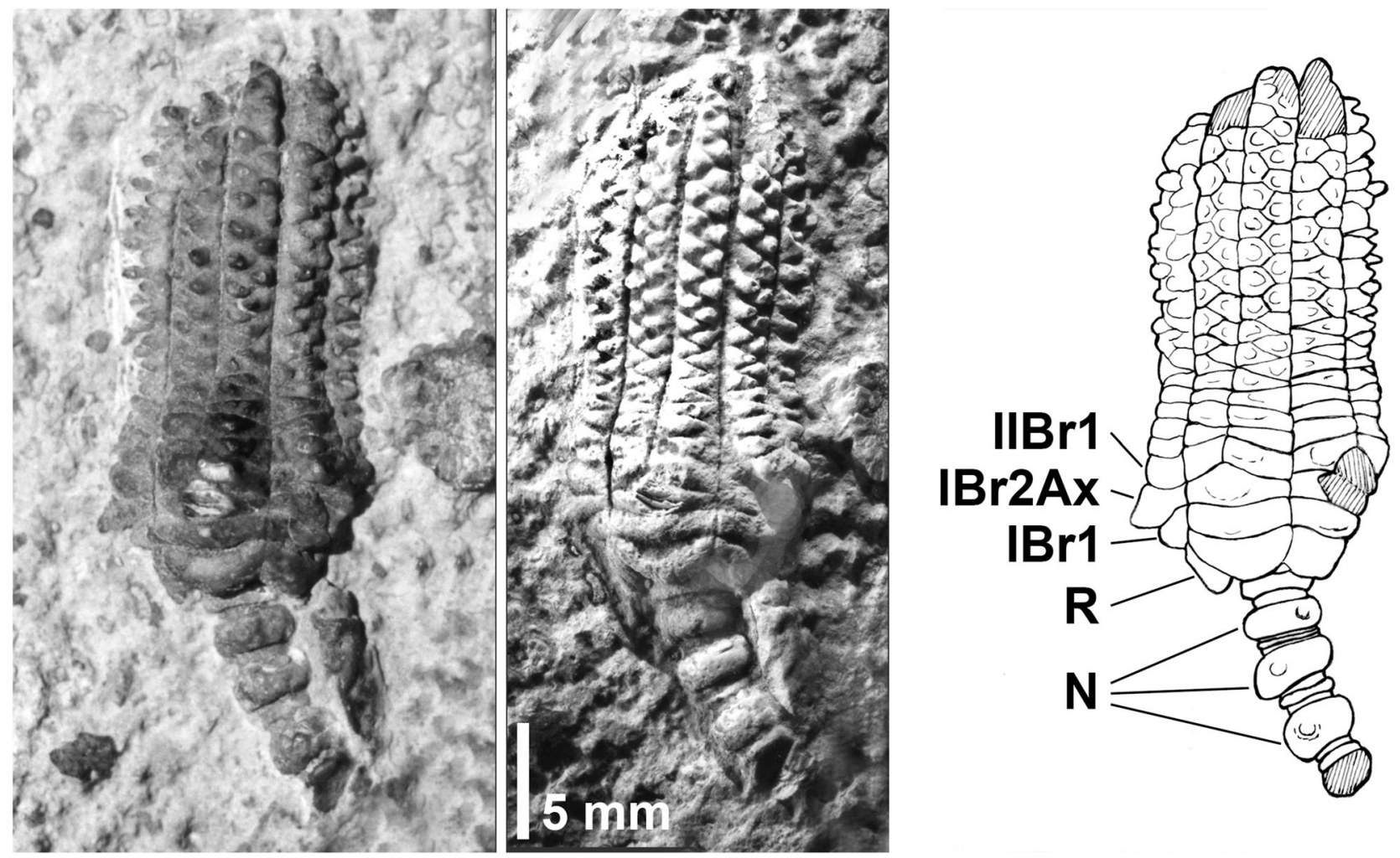

Fig. 3 Encrinus aculeatus, crown 1/1 with proximal column, Val Brembana (Alpi Orobie, Italy). Specimen in natural view, whitened with ammonium chloride, and in camera lucida sketch morphological

with extensions that may be elongated resembling a blunt spine.

First secundibrachial The dorsal side is rhombical with a central blade-shaped ornament along the transverse axis. A deep gap between the extensions of the axillaries allows outward tilting of the arm branches at the muscular axillary facets. Facets are concealed.

Subsequent brachials The subsequent proximal brachials are low and become distally increasingly wedgeshaped (Figs. 3, 4a). Their dorsal sides are ornamented with high blade-shaped extensions that run out towards the margins causing deep interbrachial indentations. Distally from secundibrachial 6 or 7, the brachials of either series do not reach the opposite margin of the arms anymore. From this point, the brachials are arranged in a manner with the interbrachial zigzag suture lines wide and forming angels of less than $90^{\circ}$ (immature biseriality). Their dorsal ornaments are blade-like spines that may be directed obliquely outwards but do not reach the margins (Figs. 3, $4 \mathrm{a}$, f, see also Fig. $7 \mathrm{~m}$ ). Thus, the straight dorsal sides of the arms have an angular marginal edge. Among juvenile crowns, arms remain uniserial with oblique interbrachial suture lines (Fig. 4b).

Pinnules The pinnules are directed upwards (Fig. $4 \mathrm{~b}, \mathrm{~d}$, e). They comprise ca. 14 pinnulars of which the first is analysis; explanations: $R$ radial, $I B r 1$ first primibrachial, $I B r 2 A x$ axillary second primibrachial, $I I B r l$ first secundibrachial, $N$ nodals with cirrus sockets

Fig. 4 Encrinus aculeatus, details from slabs 1 and 2, Val Brembana (Alpi Orobie, Italy). a Crown $1 / 2$ with proximal column. b Crown 2/5 with lost upper half, showing depressed base, sharp edges of arms, and pinnulation. c Juvenile crown $1 / 8$ of cylindrical shape, with proximal column, arms uniserial: Scale $5 \mathrm{~mm}$. d Distal arms 2/2 showing brachial ornamentation in side view and pinnulation. e Medial and distal arms 2/9 showing pinnulation and faint pectinate ornamentation of pinnulars. f Details from slab 1 with crowns 14-18, in natural, unwhitened view. a-e Whitened with ammonium chloride. Scales $10 \mathrm{~mm}$, unless otherwise indicated

shorter and thicker than the subsequent ones. Their sides are straight, and the interpinnular sutures are indistinct. Faint lateral pectinate ornamentation was observed in specimen $2 / 5$.

Column As in the typical encrinid column, nodals and internodals are distinct in the proximal part; however, in column $1 / 24$ the proximal internodals are as wide as the nodals which makes the differentiation arbitrary (Table 2). Usually, the nodals are much longer and wider than the internodals, and have a thickened rim with a rounded epifacet. In some proximal nodals, small and indistinct cirrus facets are observed. Cirri are not present in any specimen. Up to four series of internodals occur (Fig. 5a). A column fragment from the middle part, which may belong to crown $1 / 17$, comprises 16 barrel-shaped 


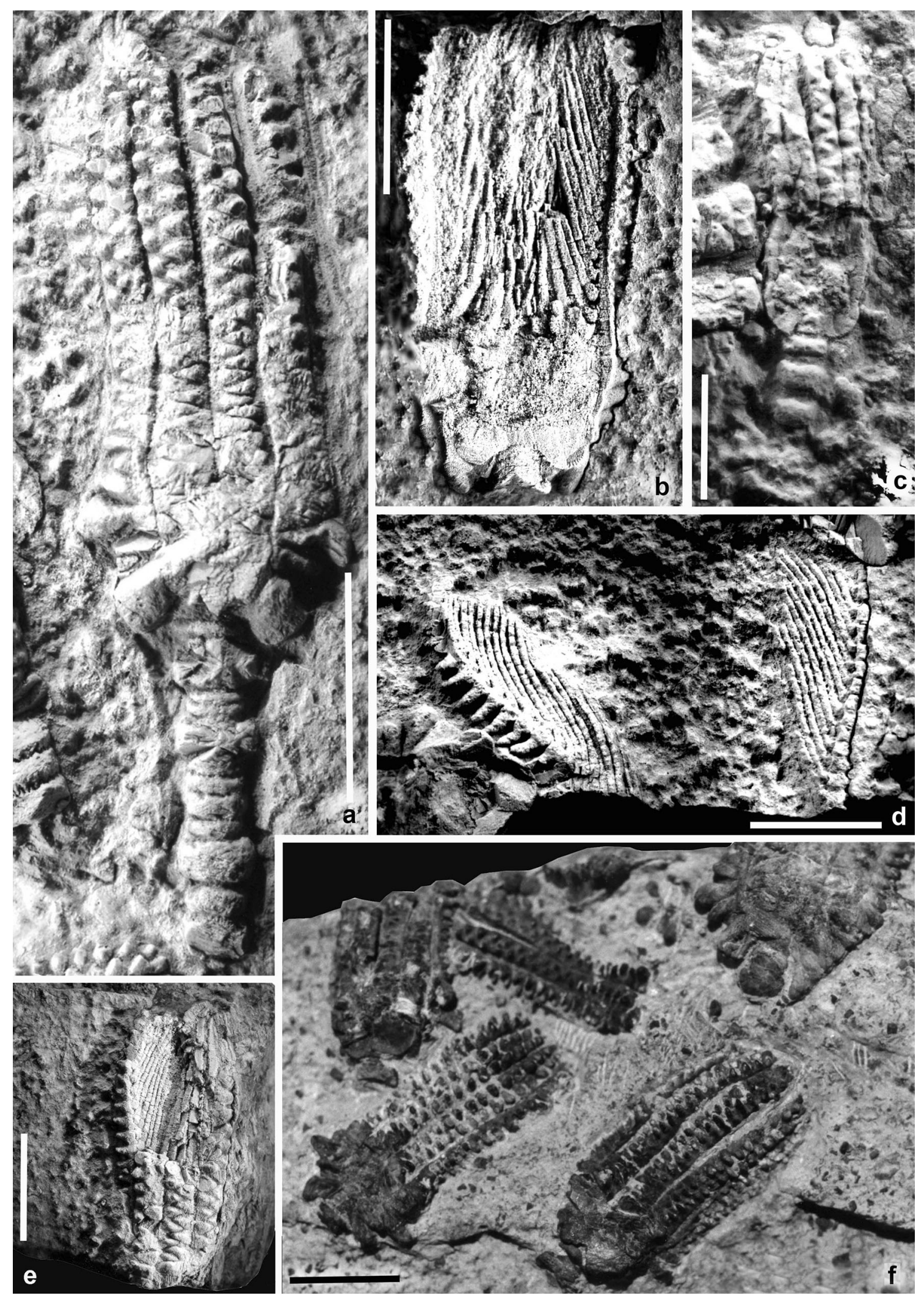




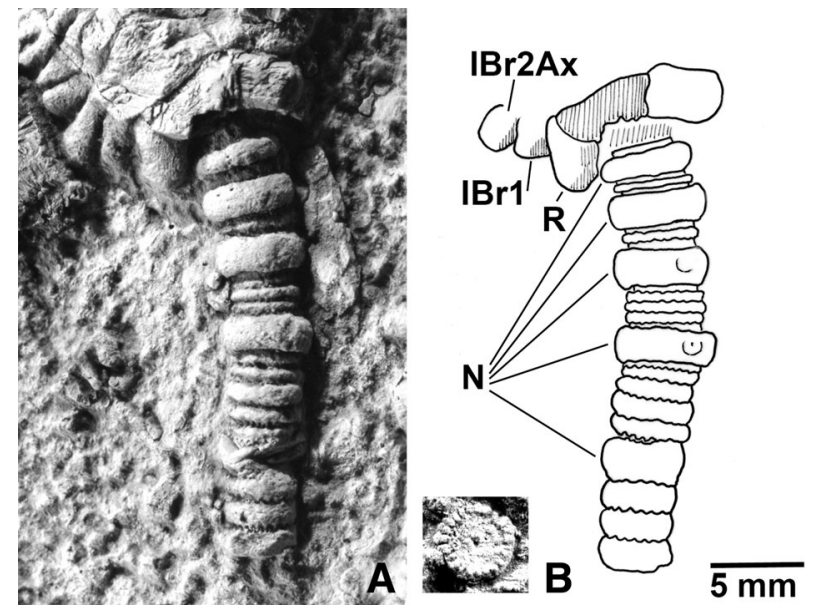

Fig. 5 Encrinus aculeatus, crown 1/11 with proximal column, Val Brembana (Alpi Orobie, Italy). a Specimen whitened with ammonium chloride, and in camera lucida sketch morphological analysis; explanations: $R$ radial, $I B r l$ first primibrachial, $I B r 2 A x$ axillary second primibrachial, $N$ nodals, some with cirrus sockets. b Columnal showing multiradiate articulation facet

columnals with slightly deepened, indistinctly crenulated suture lines (Fig. 2a). A proximal isolated columnal of $3.4 \mathrm{~mm}$ in diameter on slab 2 shows an articulate facet with ca. 20 very short multiradiate crenellae (Fig. 5b). A 3.7mm-wide distal columnal close to crown $1 / 21$ has ca. eight short and coarse radial crenellae.

Holdfast There are no holdfasts preserved on either slab.

\section{Relations}

With its ten arms, the Val Brembana crinoids clearly belong to the genus Encrinus. However, they differ in several characters from Encrinus liliiformis, the common and well-known Upper Muschelkalk (latest Illyrian) species. Additional species based on complete articulated and disarticulated specimens have been described from the Central European Muschelkalk of Germany and Poland, most of them from the late early Anisian through early late Anisian (Bithynian through early Illyrian) Lower Muschelkalk. Among these, the Val Brembana material shares most characters with Encrinus aculeatus von Meyer, 1849, a taxon established on an incomplete juvenile specimen from the "Sohlenstein" of the Friedrichsgrube (Fig. 6), a historical lead and zinc mine at Tarnowitz (Upper Silesia, now Tarnowskie Góry, Poland). Well-preserved crown and columnal specimens of juvenile and adult individuals from slightly younger sediments of the type region were assigned to Encrinus aculeatus by Assmann (1926); Figs. 7a-c, 8a). Specimens assigned to Encrinus aculeatus have also been described from the Lower
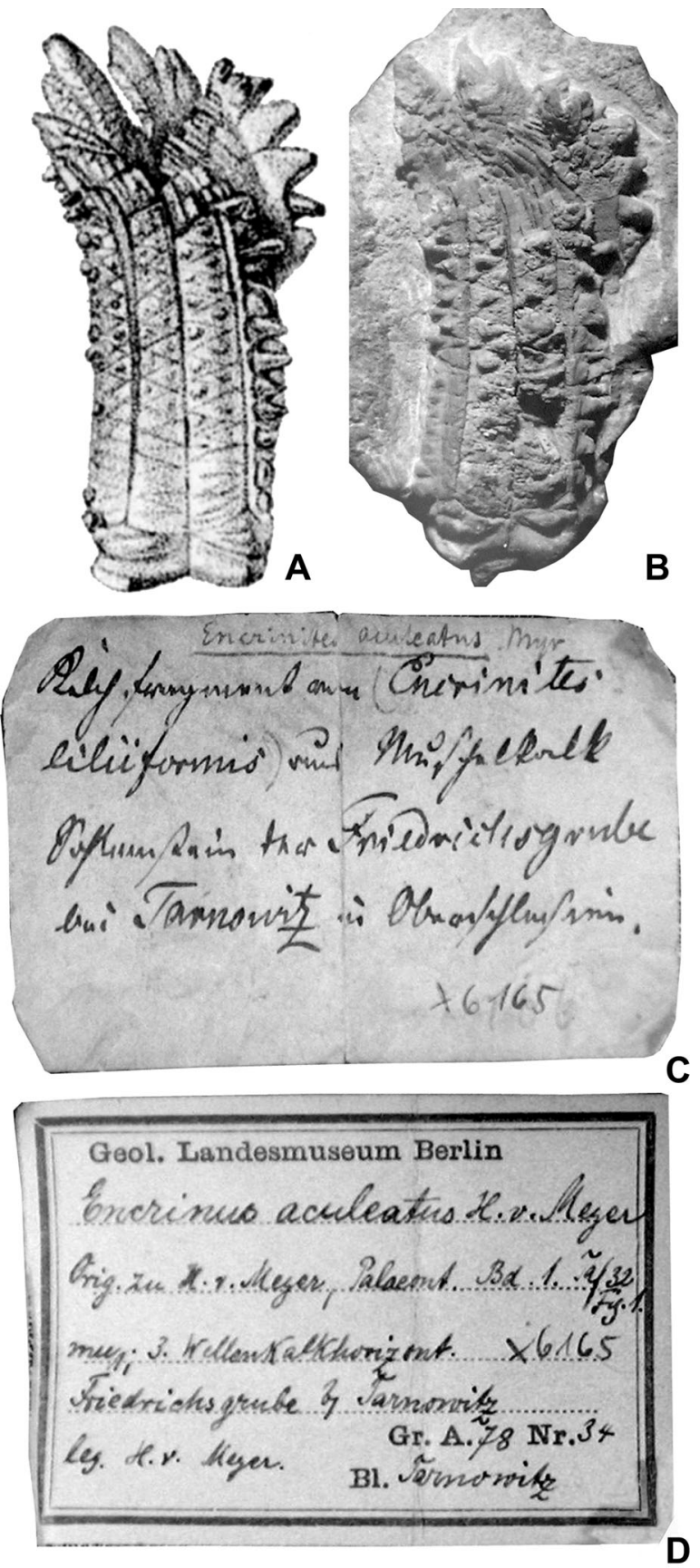

Fig. 6 Encrinus aculeatus. Original von Meyer, 1849 (holotype); BGR $\times 6165$. a After the lithography in von Meyer, 1849: pl. 32, Fig. 1. b Photography; total length $29 \mathrm{~mm}$. c Original label in old hand (Hütteninspektor Mentzel ?): Kelchfragment von Encrinites liliiformis aus Muschelkalk Sohlenstein der Friedrichsgrube bei Tarnowitz in Oberschlesien. In later hand: Encrinites aculeatus Myr. d Later label: Geol. Landesmuseum Berlin [now BGR] Encrinus aculeatus $\mathrm{H}$. v. Meyer. Orig. zu H. v. Meyer, Palaeont. Bd. 1.Taf. 32 Fig. 1. mu1; 3. Wellenkalkhorizont. Friedrichsgrube bei Tarnowitz. leg. H. v. Meyer. Gr.A. 78 Nr. 34 Bl. Tarnowitz. $\times$ 6165. The latter data refer to the Sheet Number of the Geological Map of Prussia. The collector of the specimen was Hütteninspektor Mentzel who provided most of the early 19th century fossils from the Upper Silesian Muschelkalk to the Geological Survey of Prussia 
Muschelkalk Jena-Formation of Germany (see below, synonymy list; Fig. 8b-d).

However, it has to be emphasized that the species concept of Encrinus is critical because some characters are inconsistent. In the first line, this applies to shape and size of the dorsal ornamentations of cup and arm sclerites, but also to the erection angle of basals and to the presence or lack of cirri. Dynowski and Nebelsick (2011) demonstrated that arm length and brachial ornamentation of Encrinus liliiformis reflects ecophenotypic differences depending on water depth, water flow energy and predatory pressure, comparably to the Extant West Atlantic Endoxocrinus parrae (Oji 1996). Moreover, proximal nodals may or may not bear cirri. This has also been observed among populations of Encrinus sp. cf. E. brahli (Hagdorn and Schulz 1996) and Chelocrinus schlotheimi (Hagdorn (1982).

Anyway, the Val Brembana Encrinus shares most characters with Encrinus aculeatus. These are the subhorizontal to horizontal base, the long lasting uniserial brachial pattern, the immature biserial arrangement of brachials with wide low-angle interbrachial zigzag sutures, the extremely strong dorsal ornamentation of radials and brachials, and the presence of cirrus sockets in the proximal nodals. Encrinus robustus Assmann, 1926, which occurs together with E. aculeatus, has a higher bowlshaped cup with long basals and long, less upright basals, unornamented radials and brachials, and proximal nodals devoid of cirri and indistinct epifacets (Bielert and Bielert 1995, 2000). Typical Encrinus brahli Overweg, 1850 have long, slender and poorly ornamented arms. However, the specimens described as E. sp. cf. E. brahli by Hagdorn and Schulz (1996) share characters with both typical E. brahli and E. aculeatus. Deeper water populations of Encrinus liliiformis from the Hassmersheim Member of the Upper Muschelkalk Trochitenkalk Formation may have strongly ornamented distal brachials; however, the arms of adult individuals are always advanced biserial with biseriality beginning no later than with secundibrachial 6 and the proximal brachials always devoid of ornaments. Encrinus spinosus Michael, 1883 that occurs with E. aculeatus in Upper Silesia has distal brachials with extremely elongated, hook-like spines (Fig. 7d). This character is regarded as ecophenotypic, comparable to the wide range of brachial ornamentations among the better-known Encrinus liliiformis (see above). For this reason, E. spinosus is here synonymized with E. aculeatus.

The proximal nodals of Encrinus aculeatus may have up to five cirrus scars or sockets (Fig. $8 \mathrm{c}-\mathrm{d}$ ). Because this character also occurs among E. sp. cf. E. brahli and Chelocrinus schlotheimi, isolated cirrinodals are not diagnostic of E. aculeatus with certainty. Only the strongly ornamented radials and primibrachials are likely to be assigned to $E$. aculeatus with more certainty. Under favourable circumstances, Encrinus aculeatus specimens have their original purplish pigmentation preserved (Fig. 8). The pigments have been analyzed by Wolkenstein et al. (2005) and were identified as hypericine and its diagenetically derived phenanthroperylenchinone pigments.

\section{Geographical and stratigraphical occurrence}

Encrinid sclerites with strongly ornamented dorsal sides and cirrinodals occur also in Middle Triassic sediments of the western Tethys shelf: (1) primibrachials with sack-like dorsal ornaments from the Anisian (Pelsonian through early Illyrian) Dont to Perez formations of Pra della Vacca/ Kühwiesenkopf (Braies/Prags Dolomites, South Tyrol, Italy), (2) proximal cirrinodals and strongly ornamented arm fragments from the early Ladinian (Fassanian, Avisianum Subzone) Vásolyi Formation, from Öskü (Veszprém Plateau, Hungary); uncatalogued material in MHI.

During middle to late Anisian times, Upper Silesia was closely connected to the western Tethys shelf via the open Silesian-Moravian Gate (Kozur 1974; Szulc 2000; Hagdorn 2018a). This is evidenced by a highly diverse flora and fauna including dasycladacean algae, hexactinellid sponges, hermatypic corals, echinoderms, brachiopods, and mollusks of Tethyan character that do not occur in the central parts of the Germanic Basin (Assmann 1937; Hagdorn 1985; Hagdorn and Głuchowski 1993). The Upper Silesian Lower Muschelkalk of the Opole Region is, therefore, regarded as a palaeobiogeographic extension of the Tethyan Realm.

The occurence of Encrinus aculeatus within the Germanic Basin (Germany, Poland) is confined to the Anisian (Bithynian to early Illyrian) Lower Muschelkalk and the basal Middle Muschelkalk (Diplopora Dolomite) of Poland. If the isolated material from Öskü belongs to $E$. aculeatus and if the Val Brembana Encrinus would be of Ladinian age, its range would have to be expanded. As pointed out above, it clearly differs from E. liliiformis, but this taxon is more likely to be derived from E. aculeatus than from E. robustus. This is evidenced by Encrinus aculeatus individuals with characters close to Encrinus liliiformis (Fig. 7b). The salinar Middle Muschelkalk interval of approx. 1.1 Ma devoid of stenohaline faunal elements within the Germanic Basin obscures a continuous phylogenetic transition of E. aculeatus to E. liliiformis. However, E. liliiformis must have originated from an Illyrian Encrinus that survived in shallow water of the western Tethys Realm and immigrated into the Germanic 


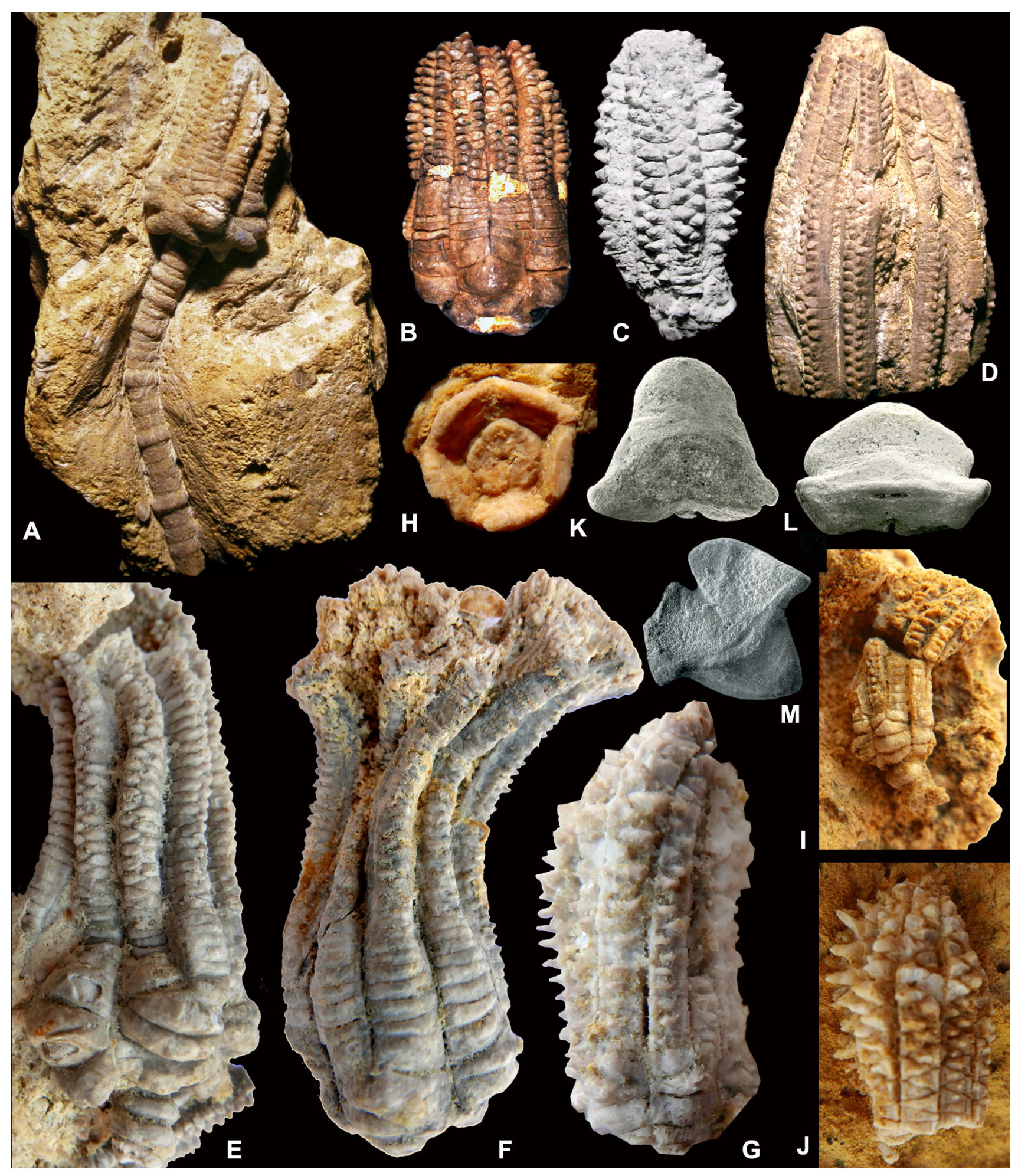


4Fig. 7 Encrinus aculeatus from Upper Silesia. a-c Originals Assmann (1926: pl. 8, Figs. 1-4), Karchowice Formation, Groß Stein (now Kamien Šląski, Polen); a semi-adult crown with proximal column, length of crown fragment $38 \mathrm{~mm}, \mathrm{BGR} \times 03270$; b semiadult crown, resembling $E$. liliiformis, length $43 \mathrm{~mm}$, BGR $\times 03269$; c distal fragment of adult crown with strongly ornamented brachials, length $47 \mathrm{~mm}$, BGR $\times$ 03271. d Original of Michael (1893, fig. p. 500; holotype of Encrinus spinosus), Górażdze Formation, Chorulla, length $61 \mathrm{~mm}, \mathrm{BGR} \times 6120$. $\mathbf{e}-\mathbf{g}$ Crowns from one limestone block, Karchowice Formation, Tarnów Opolski; e adult crown with proximal column, crown length $70 \mathrm{~mm}$, MHI 1270/1a; f adult crown with beginning of biseriality at secundibrachial 9, crown length $72 \mathrm{~mm}$, MHI 1270/2; g juvenile crown with spiny brachial ornamentation, crown length $24 \mathrm{~mm}, \mathrm{MHI}$ 1270/1b. h-j Crown fragments, Karchowice Formation, Strzelce Opolskie; h cup with deeply impressed basal circle, infrabasals in column pit visible, radials with sack-like, dorsal extensions, width $7 \mathrm{~mm}$, MHI 1268/2; i juvenile crown with proximal column, arms uniserial throughout, Crown length $15 \mathrm{~mm}$, MHI 1268/1; j fragment of distal crown, arms immature biserial with long blade-like spines on distal brachials, length $23 \mathrm{~mm}$, MHI 1268/3. k-m isolated sclerites from Middle Muschelkalk Diplopora Dolomite, Piekary Šląskie; k axillary primibrachial 2, proximal view with synostosial facet and blade-like dorsal extension, width 5.4 mm., GIUS-7-21d; l primibrachial 1, proximal view, showing muscular facet with radial and extreme blade-like dorsal extension, width $5.3 \mathrm{~mm}$, GIUS-7-21c; m proximal secundibrachial with muscular facet, blade-like extension on dorsal side, not reaching the margins, width $3.5 \mathrm{~mm}$, GIUS-7-59/21b

Basin through the Western (Alemannic) Gate via the Swiss Alps (Hagdorn 1985; Hagdorn and Głuchowski 1993; Klug et al. 2005; Hagdorn 2018a). For an up to date correlation of Alpine Tethyan and Germanic Muschelkalk ammonoid biostratigraphy and lithostratigraphy see Hagdorn (Hagdorn 2018b).

\section{Systematic Palaeontology}

Class Crinoidea Miller, 1821

Subclass Articulata Zittel, 1879

Order Encrinida Matsumoto, 1929.

Family Encrinidae Dujardin \& Hupé, 1862.

Genus Encrinus Lamarck, 1801.

Type species: E. liliiformis, by subsequent designation ICZN, 1962 (plenary powers, Op. 636). = Encrina Bronn, 1848 (nom. nullum), = Jenaicrinus Jaekel, 1918: 67 (type Encrinus cf. aculeatus von Meyer, 1847 in Wagner 1886: 28, pl. 2, Fig. 15).

Diagnosis Cup low bowl-shaped, pentagonal to subcircular, base flat; basals partly concealed in columnar pit; interradial articulations zygosynostosial or synostosial. Second primibrachial axillary; ten arms, proximally uniserial, biserial after secundibrachials four to ten; pinnular pectinate. Column moderate to very long, proximally weakly subpentagonal to cylindrical; proximal nodals thickened, with or without cirri; distal columnar facets multiradiate. Holdfast discoid or irregularly encrusting.

Encrinus aculeatus von Meyer, 1849.

1847 Encrinus aculeatus; von Meyer, p. 576-577 [nomen nudum].

v 1849 Encrinus aculeatus; von Meyer, p. 262-265, pl. 32, Fig. 1.

1857 Encrinus aculeatus; Beyrich, p. 30, 38-39, pl. 1, Fig. 16.

1886 Encrinus aculeatus; Wagner, p. 26-28, pl. 2, Fig. 14. 1891 Encrinus aculeatus; Wagner, p. 890-898, pl. 44, Fig. 5.

v 1893 Encrinus sp. Michael, p. 500-502, Figs. 1, 2.

v 1894 Encrinus spinosus; Michael, p. 23.

1903 Encrinus aculeatus; Wysogorski, p. 37, 59-60, pl. 6, Figs. 3a, b.

v 1926 Encrinus spinosus; Assmann, p. 507-508, fig. p. 507, pl. 9, Fig. 11.

v 1926 Encrinus aculeatus; Assmann, p. 509-511, pl. 8, Figs. 1-4.

1929 Encrinus aculeatus; Hildebrand and Pia, p. 131, 134-136, 138, Fig. 1.

v 1937 Encrinus spinosus; Assmann, p. 17, pl. 4, Fig. 3.

v 1937 Encrinus aculeatus; Assmann, p. 17-18, pl. 4, Figs. 4-7.

1938 Encrinus aculeatus; Gasche, p. 89-96, pl. 4, Fig. 2. v 1972 Encrinus aculeatus; Emmert, Horstig and Bayern, pl. 1, Fig. 1.

1986 Encrinus aculeatus + brahli; Głuchowski and Boczarowski, p. 193, pl. 1 figures 1-3.

1986 Encrinus + Chelocrinus; Głuchowski and Boczarowski, p. 193, pl. 1 Figs. 4-9.

v 1993 Encrinus aculeatus; Hagdorn and Głuchowski, p. 172, Fig. 10, 2-5.

1995 Encrinus aculeatus; Bielert and Bielert, p. 23-31, Figs. 3, 4.

v 1996 Encrinus aculeatus; Hagdorn, Głuchowski and Boczarowski, p. 52, pl. 1a-e.

v 1996 Encrinidae gen. et sp. indet.; Hagdorn, Głuchowski and Boczarowski, p. 55-57, pl. 2a-d.

2000 Encrinus sp. aculeatus; Bielert and Bielert, p. 138-140, pl. 1, Fig. 1.

? 2011 Encrinus aculeatus; Niedżwiedzki et al., p. 166-167, Fig. 3.

2014 Encrinus cf. aculeatus; Billert \& Linde, p. 56-64, Fig. 4, 11, 14.

Holotype by monotypy The fragmentary juvenile crown from the Lower Muschelkalk uppermost Gogolin Formation (3. Wellenkalkhorizont) of Tarnowitz, Upper Silesia (now Tarnowskie Góry, Poland) mentioned by von Meyer (1847, p. 576-577) and described and figured by von 


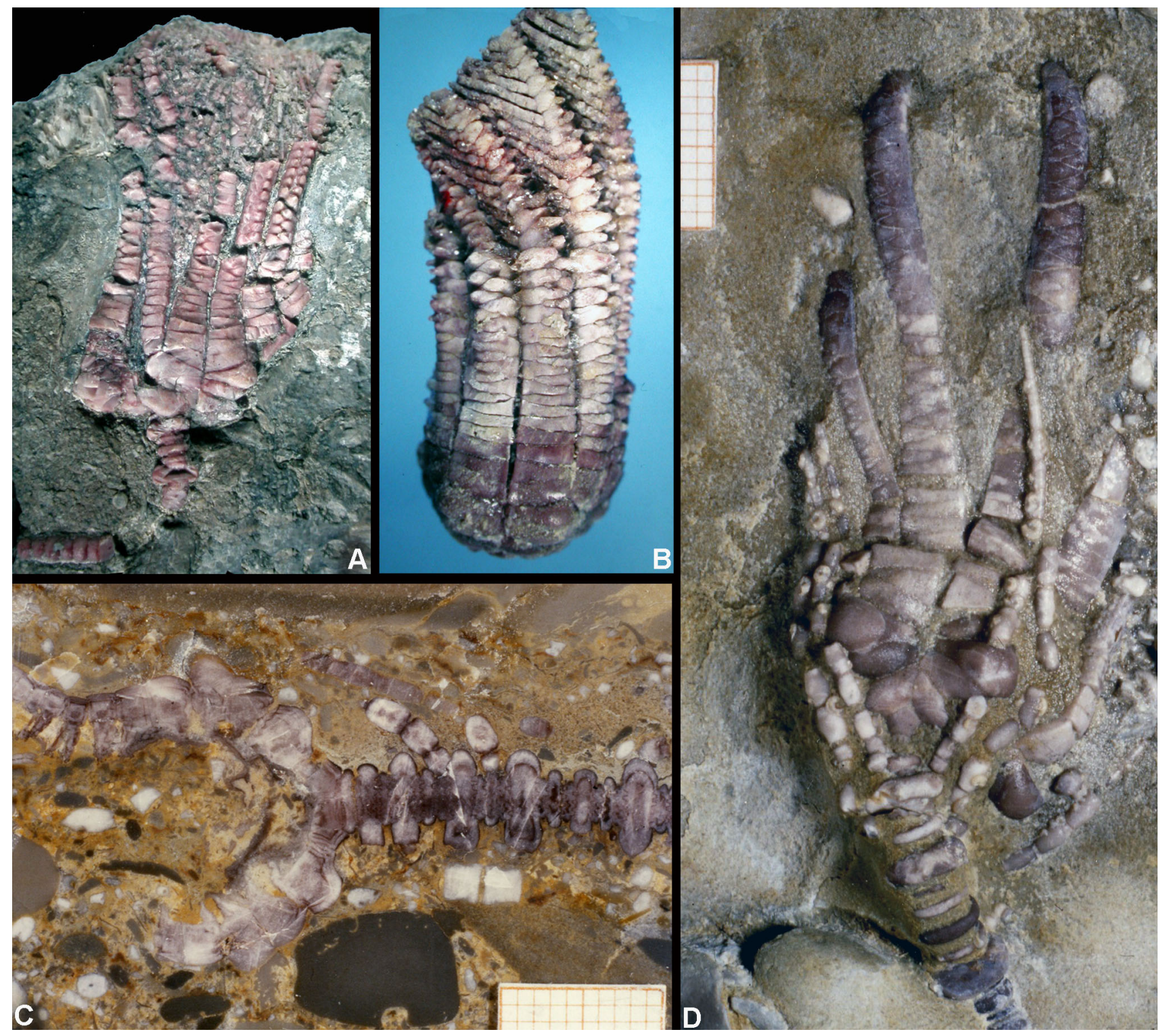

Fig. 8 Encrinus aculeatus with purplish colour pigmentation preserved. a Complete crown with proximal column, Upper Gogolin Formation, 3. Wellenkalkhorzont, Tarnowitz, Aurora Eisenförderung Mine, crown length ca. $60 \mathrm{~mm}, \mathrm{BGR} \times 13005$ (ex coll. M. Grundey). b Complete crown, immature biseriality from secundibrachial 7-9, brachials with blade-like dorsal extensions, crown length $43.5 \mathrm{~mm}$,

Meyer (1849: 262-265, pl. 32 Fig. 1): BGR $\times 6165$ (Fig. 6).

Diagnosis Medium-sized Encrinus; crown length up to $100 \mathrm{~mm}$. Cup low bowl-shaped with subhorizontal or slightly convex base. Articulations of basals and radial synostosial, radials dorsally strongly inflated. Arms of adultus biserial after secundibrachials six to seven. Proximal brachials dorsally strongly inflated, medial and distal brachials ornamented with spines or, rarely, with hooks. Column with strongly thickened proximal nodals which
NLH 52044 (ex coll. O. Klages). c-d Crowns with long cirrals at proximal nodals, Jena Formation (Bereich Basiskonglomerate), Weißenborn (Lower Saxony, Germany), SBH uncatalogued; c polished section, $\mathbf{d}$ one arm regenerating, barrel-shaped cirrals (photos Dr. F. Bielert)

may bear one to five short cirri; cirrus scars depressed or on protruding lateral extensions of nodals; cirrals barrelshaped, with faint multiradiate articulations. Pigmentation purplish, if preserved.

Range Middle Triassic, middle to late Anisian (Pelsonian, early Illyrian), (?) early Ladinian (Fassanian).

Occurrence Lower Muschelkalk: Upper Gogolin, Górażdze and Karchowice formations, Upper Silesia, Poland; JenaFormation, Germany. Middle Muschelkalk: Diplopora 
Dolomite, Upper Silesia, Poland. Prags to Perez Formations, Dolomites, Italy; ? Angolo Limestone, ? "Banco a Brachiopodi", Val Brembana, Orobic Alps, Bergamo, Italy; ? Vásolyi Formation, Veszprém Plateau, Hungary.

Material Encrinus aculeatus: two slabs with 36 more or less complete crowns, arm and column fragments from Val Brembana (MPIUM 11758; private collection M. Salmoiraghi); epoxy casts of slabs 1 and 2 MHI 2160/1, MHI 2160/2. Original von Meyer 1849: pl. 32, 1; holotype: BGR $\times$ 6165. Originals Assmann 1926: pl. 8, Figs. 1-3 (= Assmann 1937: pl. 4, Figs. 4-6): BGR × 03269; BGR $\times$ 03270; BGR 03271. Encrinus spinosus zu E. aculeatus: Original Michael 1893: Fig. p. 500; holotype: BGR x 6120). Complete crown from Tarnowitz, ex coll. Grundey: BGR x 13005. 3 complete crowns, Tarnów Opolski: MHI 1270/1a, 1270/1b, 1270/2. Juvenile crown with proximal column, Strzelce Opolskie: MHI 1268/1; cup: MHI 1268/2; distal crown fragment: MHI 1268/3. Originals Hagdorn, Głuchowski and Boczarowski 1996: pl. 1a, GIUS-7-21c (first primibrachial), pl. 1b, GIUS-7-21d (primaxillary), pl. 1d, GIUS 7-59-/21b (proximal secundibrachial). Countless isolated sclerites from different localities in Poland (Upper Gogolin, Górażdze and Karchowice Formation) and Germany (Jena Formation): MHI uncatalogued. 2 complete crowns, Jena-Formation, Königslutter am Elm: NLH 52044, NLH 50012/1. Originals of Bielert and Bielert 1995: figs. 3-4. Isolated sclerites from Prags to Perez formations, Dolomites, Italy and Vásolyi Formation, Veszprém Plateau, Hungary: MHI uncatalogued.

Acknowledgements This paper is dedicated to the memory of Dr. Dr. h.c. Hans Hess. Over many years, Hans has stimulated and fostered my (H.H.) work on Triassic echinoderms as a senior colleague and he became a paternal friend. It is a pleasure for me to gratefully contribute to this volume in commemoration of his extraordinary echinoderm work. Hanś high scientific professionalism as private paleontologist is admirable and outstanding. Our thanks go to $\mathrm{M}$. Salmoiraghi (Castellanza, Varese, Italy) who donated slab 1 to MPUM and allowed to cast slab 2, after purchasing both slabs from the collector. Thanks are also due to Prof. Dr. Edward Głuchowski (Geological Institute Silesian University Sosnowiec), Drs. W. Lindert and A. Ehling (Bundesanstalt für Geowissenschaften und Rohstoffe, Dienstbereich Berlin), Dr. Annette Richter (Niedersächsisches Landesmuseum Hannover), for allowing to study specimens in their care. We also thank Drs. F. and U. Bielert (Nussloch, Abbesbüttel) for photographs of specimens. H.H. thanks the Paleontological Museum of the Università degli Studi di Milano, for donation of resin casts of the above described Encrinus aculeatus slabs to the Muschelkalkmuseum. We would also like to thank the companies in Germany and Poland who allowed collecting of crinoid material in their quarries. Drs. Christian Klug, Zürich, and Ben Thuy, Luxembourg, are thanked for their careful reviews and valuable suggestions.

\section{References}

Arthaber, G. V. (1896). Vorläufige Mitteilung über neue Aufsammlungen in Judikarien und Berichtigung, den „Ceratites nodosus “aus dem Tretto betreffend. Verhandlungen der Geologischen Reichsanstalt, 31, 265.

Assereto, R., \& Casati, P. (1965). Revisione della stratigrafia permotriassica della Val Camonica meridionale (Lombardia). Rivista Italiana di Paleontologia e Stratigrafia, 71, 999-1097.

Assmann, P. (1926). Die Fauna der Wirbellosen und die Diploporen der oberschlesischen Trias mit Ausnahme der Brachiopoden, Lamellibranchiaten, Gastropoden und Korallen. Jahrbuch der preußischen geologischen Landesanstalt, 45 (für 1925), 504-577.

Assmann, P. (1937). Revision der Fauna der Wirbellosen der oberschlesischen Trias. Abhandlungen der preußischen geologischen Landesanstalt, 170, 1-134.

Balini, M. (1992). New genera of Anisian ammonoids from the Prezzo Limestone (Southern Alps). PhD thesis, Università degli Studi di Milano, Dipartimento di Scienze della Terra.

Benecke, E. W. (1868). Ueber einige Muschelkalk-Ablagerungen der Alpen. Geognostisch-Paläontologische Beiträge, 2(1), 5-67.

Berra, F., Rettori, R., \& Bassi, D. (2005). Recovery of carbonate platform production in the Lombardy Basin during the Anisian: paleoecological significance and constrain on paleogeographic evolution. Facies, 50(3-4), 615-627.

Beyrich, E. (1857). Über die Crinoiden des Muschelkalks. Abhandlungen der königlichen Akademie der Wissenschaften zu Berlin, 1857, 1-49.

Bielert, U., \& Bielert, F. (1995). Encriniden aus dem Bereich der Basiskonglomeratbänke des Unteren Muschelkalks von Weißenborn (Südniedersachsen). Der Aufschluss, 46, 23-31.

Bielert, U., \& Bielert, F. (2000). Gemeinsames Auftreten von zwei Arten der Gattung Encrinus im Unteren Muschelkalk am Nordrand des Thüringer Beckens. Beiträge zur Geologie von Thüringen, N. F., 7, 137-145.

Biese, W. (1934). Crinoidea triadica. Fossilium Catalogus I: Animalia, Pars 66 (p. 255). Berlin: Junk.

Billert, T., \& Linde, C. (2014). Crinoiden aus dem Unteren Muschelkalk des Pennickentals bei Jena-Wöllnitz. Der Steinkern. Fossilienzeitschrift der Internet-Community, 16, 54-67.

Brack, P., Rieber, H., \& Urlichs, M. (1998). Pelagic Successions in the Southern Alps and their correlation with the Germanic Middle Triassic. Zentralblatt für Geologie und Paläontologie Teil I, 1998(7-8), 813-852.

Dynowski, J. F., \& Nebelsick, J. H. (2011). Ecophenotypic variations of Encrinus liliiformis (Echinodermata: Crinoidea) from the middle Triassic Muschelkalk of Southwest Germany. Swiss Journal of Palaeontology, 130(1), 53-67.

Emmert, U., Horstig, X., \& von Bayern, G. (1972). Geologische Karte von Bayern 1:25000. Erläuterungen zu Blatt 5734 Wallenfels (p. 240). München: Bayerisches geologisches Landesamt.

Gaetani, M. (1969). Osservazioni paleontologiche e stratigrafiche sull' Anisico delle Giudicarie (Trento). Rivista Italiana di Paleontologia e Stratigrafia, 75(3), 469-546.

Gaetani, M., Gianotti, R., Jadoul, F., Ciarapica, G., Cirilli, S., Lualdi, A., Passeri, L., Pellegrini, M. \& Tannoia, G. (1986). Carbonifero superiore, Permiano e Triassico nell'area Lariana. Memorie di Societá Geologica d́ Italia, 32 (1986), 5-48.

Gasche, E. (1938). Ein Crinoidenkelch aus dem Hydasp (der untersten Mitteltrias) der Nördlichen Kalkalpen Oberösterreichs. Neues Jahrbuch für Mineralogie etc Beil.-Bd., 80, 72-112.

Głuchowski, E., \& Boczarowski, A. (1986). Crinoids from the Diplopora-Dolomite (Middle Muschelkalk) of Piekary Slaskie, Upper Silesia. Bulletin of the Polish Akademy of Sciences. Earth Sciences, 34, 189-196.

Hagdorn, H. (1982). Chelocrinus schlotheimi (Quenstedt) 1835 aus dem Oberen Muschelkalk (mo1, Anisium) von 
Nordwestdeutschland. Veröffentlichungen des Naturkundemuseums Bielefeld, 4, 5-33.

Hagdorn, H. (1985). Immigration of crinoids into the German Muschelkalk Basin. In U. Bayer \& A. Seilacher (Eds.), Sedimentary and evolutionary cycles (= Lecture Notes in Earth Sciences 1) (pp. 237-254). Berlin: Springer.

Hagdorn, H. (2018a). Paläobiogeographie des Mitteleuropäischen Beckens in der Frühen und Mittleren Trias und Fauneneinwanderung ins Muschelkalkmeer. In Deutsche Stratigraphische Kommission (Ed.; Koordination und Redaktion: Hagdorn, H., Simon, T., für die Subkommission Perm-Trias): Stratigraphie von Deutschland XIII. Muschelkalk. Schriftenreihe Deutsche Gesellschaft für Geowissenschaften, 91). Hannover: Schweizerbart (in press).

Hagdorn, H. (2018b). Biostratigraphie der Muschelkalk-Cephalopoden. In Deutsche Stratigraphische Kommission (Ed.; Koordination und Redaktion: Hagdorn, H., Simon, T., für die Subkommission Perm-Trias): Stratigraphie von Deutschland XIII. Muschelkalk. Schriftenreihe Deutsche Gesellschaft für Geowissenschaften, 91). Hannover: Schweizerbart (in press).

Hagdorn, H., \& Głuchowski, E. (1993). Palaeobiogeography and Stratigraphy of Muschelkalk Echinoderms (Crinoidea, Echinoidea). In H. Hagdorn \& A. Seilacher (Eds.), Muschelkalk. Schöntaler Symposium 1991 (= Sonderbände der Gesellschaft für Naturkunde in Württemberg 2) (Vol. 176, p. 165). Stuttgart: Goldschneck.

Hagdorn, H., Głuchowski, E., \& Boczarowski, A. (1996). The crinoid Fauna of the Diplopora-Dolomite (Middle Muschelkalk, Triassic, Upper Anisian) at Piekary Slaskie in Upper Silesia. Geologisch-paläontologische Mitteilungen Innsbruck, 21, 47-87.

Hagdorn, H., \& Schulz, M. (1996). Echinodermen-Konservatlagerstätten im Unteren Muschelkalk Osthessens. 1. Die Bimbacher Seelilienbank von Großenlüder-Bimbach. Geologisches Jahrbuch Hessen, 124, 97-122.

Hildebrand, E., \& Pia, J. (1929). Zwei Crinoidenkelche aus der Anisischen Stufe der Südalpen. Paläontologische Zeitschrift, 11(2), 129-140.

Jadoul, F., Berra, F., Bini, A., Ferliga, C., Mazzoccola, D., Papani, L., Piccin, A., Rossi, R., Rossi, S. \& Trombetta, G. I. (2012). Note Illustrative della Carta Geologica d 'Italia alla scala 1:50.000, Foglio 077 Clusone. ISPRA, Servizio Geologico d'Italia.

Klug, C., Schatz, W., Korn, D., \& Reisdorf, A. G. (2005). Morphological fluctuations of ammonoid assemblages from the Muschelkalk (Middle Triassic) of the Germanic Basin-indicators of their ecology, extinctions, and immigrations. Palaeogeography, Palaeoclimatology, Palaeoecology, 221, 7-34.
Kozur, H. (1974). Biostratigraphie der germanischen Mitteltrias. Freiberger Forschungshefte C 280: Teil 1, 56 pp., Teil 2, 71 pp., Teil 3, 15 Anl.

von Meyer, H. (1847). Mitteilung an Professor Bronn (pp. 572-580). Geologie und Petrefaktenkunde: Neues Jahrbuch für Geognosie.

von Meyer, H. (1849). Fische, Crustaceen, Echinodermen und andere Versteinerungen aus dem Muschelkalk Oberschlesiens. Palaeontographica., 5, 216-242.

Michael, R. (1893). Encrinus sp. von Chorulla. Ober-Schlesien. Zeitschrift der deutschen geologischen Gesellschaft, 45, 500-502.

Michael, R. 1894: Über einen neuen Encrinus aus dem oberschles. Muschelkalk. - Jahresberichte derschlesischen Gesellschaft für vaterländische Naturkunde, 71(2), 23

Monnet, C., Brack, P., Bucher, H., \& Rieber, H. (2008). Ammonoids of the middle/late Anisian boundary (Middle Triassic) and the transgression of the Prezzo Limestone in eastern Lombardygiudicarie (Italy). Swiss Journal of Geosciences, 101(1), 61-84.

Niedžwiedzki, R., Salamon, M., \& Wolkenstein, K. (2011). Encrinus aculeatus (Crinoidea: Encrinida) with exceptional preservation of organic pigments from the Middle Triassic of Lower Silesia (SW Poland). Neues Jahrbuch für Geologie und Paläontologie, Abh., 262(2), 163-170.

Oji, T. (1996). Is predation intensity reduced with increasing depth? Evidence from the west Atlantic stalked crinoid Endoxocrinus parrae (Gervais) and implications for the Mesozoic marine evolution. Paleobiology, 22, 339-351.

Seilacher, A., \& Westphal, F. (1971). Fossil-Lagerstätten." VIII. International Sedimentological Congress, Guidebook (pp. 327-353). Frankfurt: W. Kramer.

Szulc, J. (2000). Middle Triassic evolution of the northern PeriTethys area as influenced by early opening of the Tethys Ocean. Annales Societatis Geologorum Poloniae, 70, 1-48.

Wagner, R. (1886). Die Encriniten des unteren Muschelkalkes von Jena. Jenaische Zeitschrift für Naturwissenschaft, 20 (N.F.13), $1-32$.

Wagner, R. (1891). Ueber einige Versteinerungen des unteren Muschelkalks von Jena. Zeitschrift der deutschen geologischen Gesellschaft, 43, 879-901.

Wolkenstein, K., Gross, J. H., Falk, H., \& Schöler, H. (2005). Preservation of hypericin and related polycyclic quinone pigments in fossil crinoids. Proceedings of the Royal Society of London, B, 273, 451-456.

Wysogorski, J. (1903). Die Trias in Oberschlesien. In Frech, F. (Ed.), Lethaea Geognostica. Handbuch der Erdgeschichte II, Tl. Das Mesozoikum, 1. H. Die Trias, 1. Liefg., 54-64. Stuttgart: Schweizerbart. 